\title{
Kopi Luwak: From Monopolistic Competition to Monopoly?
}

Kopi Luwak is the famous kind of coffee from Indonesia. This coffee is called Kopi Luwak because it is produced from civet digestion. In the digestion of civet, coffee beans become fermented so that the resulting coffee taste is more unique than coffee in general. This unique method of making is what makes civet coffee become booming in the international market. Because this coffee is very unique, this coffee became booming and international market demand is exploding. It takes a long time to make the coffee, because this coffee is based on civet digestion. So the supply cannot meet demand. (Pratono \& Radjamin, 2012)

Because international market demand is increasing every day, some small farmers form The Association of Indonesian Coffee Luwak Farmers in 2009. They are small farmers with the same products, but they have international market access and become one unit to fulfill the international market. This is similar to monopolistic, because there are many sellers with the same goods. (Etro, 2019)

PTPN XII is the largest Kopi Luwak producer in Indonesia. PTPN XII have 600 civets in four plantation areas. In 2010, PTPN XII wanted to try to convert Arabian Coffee to Kopi Luwak to fulfil the international market demand. This makes PTPN XII known more professional than other local competitors. Not only the largest Kopi Luwak producer in Indonesia, PTPN have another companies that dominate the market of palm oil, rubber, sugar cane, and tobacco, and other similar supplies. This makes PTPN become the first choice for consumers to meet their daily needs. Consumers will certainly choose to buy goods directly from PTPN. thus, small producers become less interested and eventually will close by themselves. So that PTPN is the only Luwak Coffee producer in Indonesia. PTPN no longer has a rival for Kopi Luwak. (Caravaggio \& Sodini, 2019)

\section{References}

Caravaggio, A., \& Sodini, M. (2019). Monopoly with differentiated final goods and heterogeneous markets. Chaos, Solitons \& Fractals.

Etro, F. (2019). Monopolistic competition for the market with heterogeneous firms. Economic Letters volume 179, 9-12.

Pratono, A. H., \& Radjamin, I. P. (2012). Emerald Case Study: Kopy Luwak: a conservation strategy for global market. Emerging Markets Case Studies Collection, 1-5. 